М. Ю. Шкуро, аспірант

e-mail: skuro_mu@meta.ua

Київський національний університет будівництва і архітектури, просп. Повітрофлотський, 31, м. Київ, 03037, Україна

\title{
КОНЦЕПТУАЛЬНА МОДЕЛЬ СИСТЕМИ УПРАВЛІННЯ ПРОЕКТАМИ ПІДВИЩЕННЯ МУНІЩИПАЛЬНОЇ ЕНЕРГОЕФЕКТИВНОСТІ
}

Обтрунтовано шляхи вирішення проблеми підвищення муніципальної енергоефективності із застосуванням проектного підходу. Зроблено аналіз літератури щодо підвищення енергоефективності і дослідження стандартів в галузі управління проектами. Представлена концептуальна модель проекту підвищення муніципальної енергоефективності і сформульовано вимоги до неї. Концептуальна модель включає чотири аспекти - технологічний, організаційний, управлінський і інформаційний. Постульовано, що в кониептуальну модель необхідно провести трансфер моделей иих аспектів. Визначені суттєві характеристики кожного аспекту для здійснення ефективного трансферу. Формалізовано модель оиінювання рішень з енергоефективності для вибору оптимального рімення. Сформульований підхід холістичного бачення до проекту підвищення муніципальної енергоефективності. Визначені елементи холістичного бачення у окремих підсистемах системи управління проектом. Розроблена послідовність реалізації періодичного иілісного моніторингу проекту підвищення муніципальної енергоефективності.

Ключові слова: управління проектами, муніципальна інфраструктура, енергоефективність, холізм, синергетизм, проактивність.

\section{Постановка проблеми}

Вектор європейської інтеграції, що визначений в Україні на державному рівні, недостатня ефективність українського виробництва і заощадливість житлово-комунального господарства вимагають від нашої країни впровадження прогресивних енергоощадних технологій.

Один 3 найважливіших вимірів у впровадженні енергоефективних технологій - муніципальний. Саме муніципальне господарство, яке характеризується низькою енергоефективністю, потребує модернізації для забезпечення конкурентоспроможності економіки України серед країн Європейського Союзу.

Підвищення енергоефективності муніципального господарства має розглядатися як діяльність, що має яскраво виражені проектні риси. Отже, для ефективної реалізації такої діяльності їі необхідно розглядати як портфель (або, скоріше, програму) проектів, що взаємопов'язані.

Для кожного проекту, який може розглядатися як такий, що належить до окремого класу проектів - проектів підвищення муніципальної енергоефективності, необхідно розробити моделі і методи, що покращують його управління і забезпечують збільшення ймовірності отримання продукту проекту в межах визначених обмежень.
Розробка моделей проектів зазвичай починається 3 концептуальної моделі, чому i присвячена ця стаття.

\section{Аналіз останніх досліджень}

Проблеми енергоефективності, зокрема у регіональному вимірі, стали предметом грунтовних досліджень [1]. Необхідність і актуальність підвищення енергоефективності економіки України підтверджується вже хоча б тим фактом, що у 2014 році було перекладено і включено до переліку державних стандартів України стандарт ISO 3 енергетичного менеджменту [2].

Моделі і методи проекту підвищення муніципальної енергоефективності (далі проект ПМЕ) мають базуватися на сучасних стандартах i напрацюваннях українських i зарубіжних вчених у галузі проектного менеджменту.

Важливим у цьому сенсі є використання стандарту з оцінювання індивідуальної компетентності фахівців у галузі управління проектами [3], який не тільки визначає вимоги до фахівців, а й дає уявлення про більшість аспектів проектної діяльності.

Управління сукупностями проектів енергоефективності доцільно будувати на основі комбінації стандартів з управління портфелями і програмами $[4,5], 3$ використанням на- 
працювань найвідомішого стандарту у галузі управління проектами РМBOK [6].

Для того, щоб адекватно перенести моделі управління і адаптувати їх до вимог проекту, використовується модель трансферу технологій, що описана в літературі $[7,8]$.

I для збереження при цьому цілісності проекту і його системи управління, деякі автори $[9,10]$ рекомендують застосовувати принцип холістичного бачення.

Метою статті $\epsilon$ формулювання концептуальної моделі проекту підвищення муніципальної енергоефективності, розробка управлінських інструментів, що доповнюють концептуальну модель - моделі підтримки прийняття рішень щодо енергоефективності, підходу холістичного бачення, підходу щодо проведення цілісного моніторингу проекту.

\section{Виклад основного матеріалу}

Концептуальна модель системи управління проектами підвищення муніципальної енергоефективності має включати усі сучасні напрацювання, що стосуються галузей знань, які мають використовуватися в проектах ПМЕ, а також інтеграційну компоненту.
Сформулюємо вимоги до такої моделі:

- наукова обгрунтованість використовуваних елементів;

- актуальність (сучасність) використовуваних елементів;

- концептуальна модель має забезпечувати гнучкість системи управління;

- система управління, що визначена концептуальною моделлю, має періодично та/або ситуативно оновлюватися;

- концептуальна модель має передбачати інструменти технологічного випередження конкурентів (або забезпечення лідерства у галузі);

- обов'язковим елементом концептуальної моделі має бути прогнозування поведінки зовнішнього і внутрішнього проектного середовища (проактивність);

- ефективна інтеграція і несуперечливість використовуваних моделей, методів, інструментів та інших елементів концептуальної моделі.

На основі вище викладених вимог, запропонуємо концептуальну модель проектів ПМЕ (рис. 1).

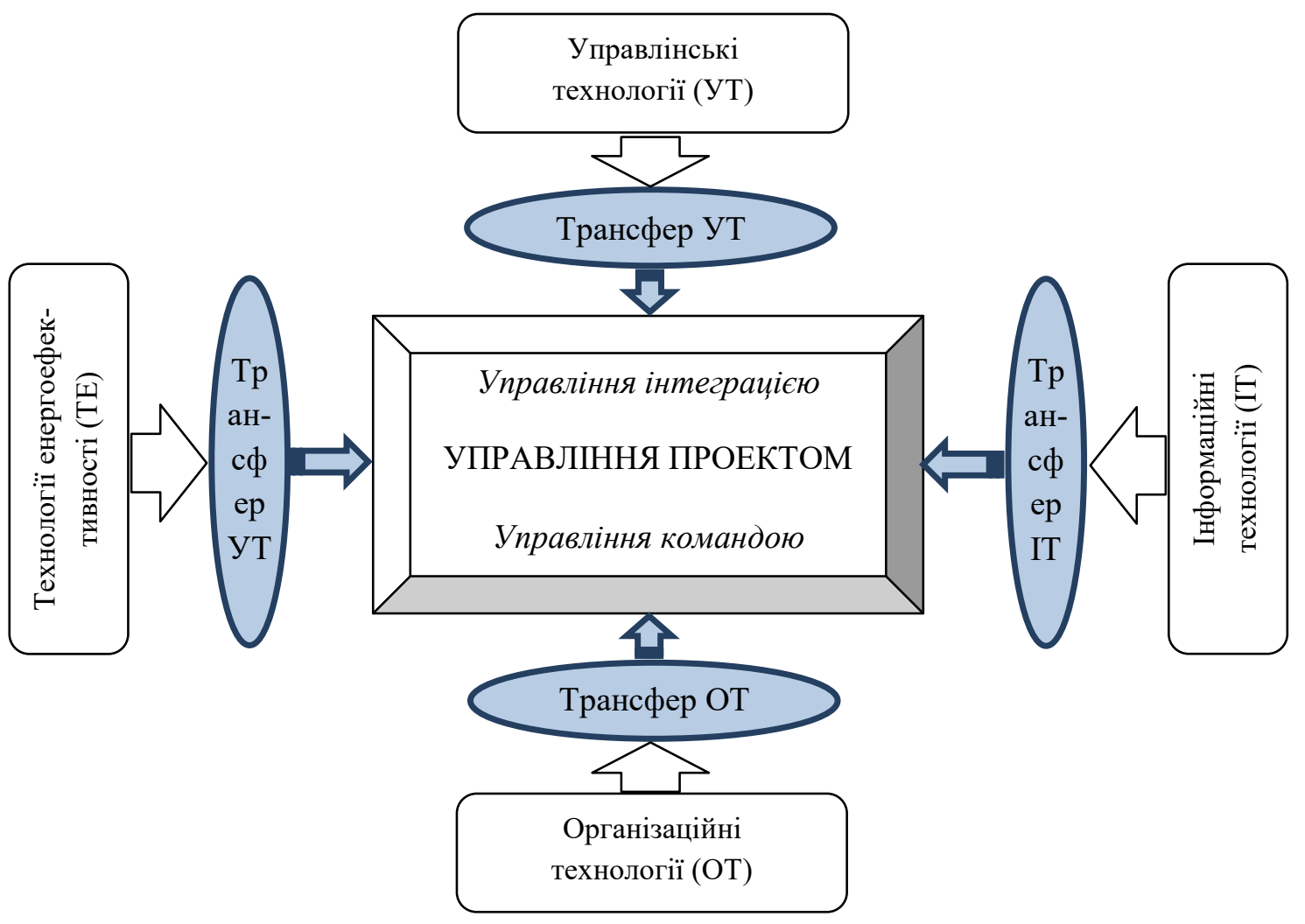

Рис. 1. Концептуальна модель проекту ПМЕ 
У наведеній моделі об'єднано чотири суттєвих аспекти проекту - технологічний, організаційний, управлінський і інформаційний.

Враховуючи особливості кожного з наведених аспектів, визначимо суттєві характеристики кожного 3 них для здійснення ефективного трансферу в систему управленні проектом ПМЕ (табл. 1).

Таблиця 1

Характеристика аспектів проекту ПМЕ

\begin{tabular}{|c|c|c|}
\hline № & Аспект & Характеристика аспекту \\
\hline 1. & $\mathrm{TE}$ & $\begin{array}{l}\text { - } \text { Інноваційність; } \\
\text { - Прогресивність; } \\
\text { - } \text { Апробованість; } \\
\text { - Сумісність } 3 \text { існуючим об- } \\
\text { ладнанням; } \\
\text { - Можливість подальшого } \\
\text { розвитку. }\end{array}$ \\
\hline 2. & УT & $\begin{array}{ll}\text { - } & \text { Сучасність; } \\
\text { - } & \text { Проектний підхід; } \\
\text { - } & \text { Проактивність; } \\
\text { - } & \text { Гнучкість (Agile); } \\
\text { - } & \text { Холізм. }\end{array}$ \\
\hline 3. & IT & $\begin{array}{ll}\text { - } & \text { Мультиплатформеність; } \\
\text { - } & \text { Інтегрованість; } \\
\text { - } & \text { Адаптивність; } \\
\text { - Масштабованість; } \\
\text { - }\end{array}$ \\
\hline 4. & OT & $\begin{array}{ll}\text { - } & \text { Гнучкість оргструктури; } \\
\text { - } & \text { Ефективна мотивація; } \\
\text { - } & \text { «Скриньки» якості; } \\
\text { - } & \text { Командна робота; } \\
\text { - } & \text { Орієнтація на результат. }\end{array}$ \\
\hline
\end{tabular}

Основним акцентом проектів ПМЕ $є$ впровадження кращих (за умов існуючих обмежень і припущень) рішень щодо енергоефективності.

Отже, необхідно запропонувати метод вибору кращого (оптимального) рішення щодо енергоефективності.

Вихідними даними для вирішення цієї задачі будуть деякі критерії енергоефективності $k^{e}$, які потрібно визначити. Далі критерії мають отримати вагу для кожного типу рішення. Після цього їх необхідно оцінити (наприклад, експертно). Окрім цього, сукупність критеріїв може впливати на енергоефективність інакше, ніж їх проста сума. Виникає явище синергетизму (який, проте, може бути i від’ємним), яке теж має бути оціненим.
Таким чином, модель оцінювання рішень для вибору кращого (оптимального) 3 них можемо сформулювати у вигляді:

$$
\begin{aligned}
& R_{j}^{1}=\sigma_{1} \cdot w_{1} \cdot\left(E_{1}^{j, 1} \cdot k_{1}^{e}+\cdots+E_{i}^{j, 1} \cdot k_{i}^{e}+\cdots\right. \\
& \left.\quad+E_{I}^{j, 1} \cdot k_{I}^{e}\right)=\sigma_{1} \cdot w_{1} \cdot \sum_{i=1}^{I}\left(E_{i}^{j, 1} \cdot k_{i}^{e}\right)
\end{aligned}
$$

де $\quad R_{j}^{1}-$ оцінка $j$-го варіанта рішення першим експертом;

$\sigma_{1}$ - оцінка синергетичного ефекту від сукупної дії усіх критеріїв енергоефективності, що дана першим експертом;

$w_{1}$ - вага першого експерта в експертній групі;

$E_{i}^{j, 1}$ - оцінка, що дана першим експертом, $i$-му критерію за $j$-им рішенням щодо енергоефективності;

$k_{i}^{e}-$ критерій енергоефективності $i$-го параметру рішення.

Оцінка $j$-го рішення експертною групою, що складається з $F$ експертів отримаємо за формулою:

$$
R_{j}=\sum_{f=1}^{F}\left(\sigma_{f} \cdot w_{f} \cdot \sum_{i=1}^{I}\left(E_{i}^{j, f} \cdot k_{i}^{e}\right)\right)
$$

Особі, що приймає рішення, надається результат оцінювання експертною групою $J$ рішень щодо енергоефективності $R_{1}, R_{2}, \ldots R_{J}$ 3 рекомендацією розглядати до прийняття три рішення 3 найбільшими значеннями $R_{j}$.

Іншим аспектом проекту ПМЕ, що потребує розгляду, є його комплексна складність. Багато аспектів проекту мають сукупно управлятися, а отже необхідно застосовувати системне, цілісне управління. Для його здійснення застосуємо підхід управління, що передбачає формування і втілення холістичного бачення проекту - підхід холізму.

Холістичне бачення має на увазі врахування усіх аспектів проекту i здійснення управління ними 3 урахуванням взаємовпливу аспектів один на одного і сукупного впливу аспектів на систему. Так, що одним 3 важелів і факторів управління є синергетичний ефект.

Визначимо елементи холістичного бачення у окремих підсистемах системи управління проектом ПМЕ (табл. 2).

В таблиці вказані десять галузей знань в управлінні проектами 3 останньої редакції стандарту PMBOK, а також елементи холістичного бачення, що мають реалізовуватися в 
межах цих галузей, підтримуючи холізм системи управління проектом ПМЕ.

Основними елементами холістичного бачення $є$ використання проактивності (прогнозування при управлінні), оптимізація ресурсів, командна робота групи управління проектом і трансформація конфліктів, що виникають у проекті ПМЕ, у його рушійні сили (а не спротиви).

Таблиця 2

Елементи холізму в проекті ПМЕ

\begin{tabular}{|l|l|l|}
\hline № & $\begin{array}{l}\text { Підсистема системи } \\
\text { управління проектом }\end{array}$ & $\begin{array}{l}\text { Елемент холіс- } \\
\text { тичного бачення }\end{array}$ \\
\hline 1. & $\begin{array}{l}\text { Управління інтеграці- } \\
\text { єю }\end{array}$ & $\begin{array}{l}\text { Врахування } \\
\text { взаємовпливу }\end{array}$ \\
\hline 2. & Управління змістом & $\begin{array}{l}\text { Технологічні } \\
\text { інновації }\end{array}$ \\
\hline 3. & Управління розкладом & Проактивність \\
\hline 4. & Управління вартістю & Оптимізація \\
\hline 5. & Управління якістю & Синергетизм \\
\hline 6. & Управління ресурсами & $\begin{array}{l}\text { Командна робо- } \\
\text { та }\end{array}$ \\
\hline 7. & Управл. комунікаціями & $\begin{array}{l}\text { Трансформація } \\
\text { конфліктів }\end{array}$ \\
\hline 8. & Управління ризиками & Проактивність \\
\hline 9. & Управління поставками & Оптимізація \\
\hline 10. & $\begin{array}{l}\text { Управл. стейкхолдера- } \\
\text { ми }\end{array}$ & Консенсус \\
\hline
\end{tabular}

Напрацювання щодо енергоефективності і холістичного бачення проекту ПМЕ мають бути не тільки коректно розроблені, але й ефективно впроваджуватися. Для цього необхідно сформулювати певний підхід (який у подальшому може трансформуватися у модель і далі у алгоритм) щодо проведення моніторингу проекту ПМЕ. Зазначений підхід, на відміну від існуючих, повинен мати акцент на відслідковуванні аспектів синергетизму, проактивності і холістичного бачення проекту.

В межах підходу щодо проведення цілісного моніторингу проекту ПМЕ виділимо три основних підсистеми системи управління проектом - підсистему управління інтеграцією, підсистему управління розкладом, підсистему управління командою.

Послідовність реалізації періодичного цілісного моніторингу проекту ПМЕ в межах пропонованого підходу можна визначити наступним чином.

Спершу проводиться збір актуальних даних щодо виконання проекту в межах підсистем управління розкладом та управління ресурсами.
На другому етапі оцінюється технологічна складова (що стосується рішень щодо енергоефективності в продукті проекту), прогрес у ії втіленні і аналізується необхідність змін в межах підсистеми управління змістом проекту.

На третьому етапі визначається попереднє бачення інтеграційних впливів на проект, які б здійснювали впливи, що давали б синергетичний ефект.

На четвертому етапі оцінюються зміни в похідних підсистемах за звітний період підсистемах управління вартістю, якістю, поставками.

На п'ятому етапі має проводитися глибокий аналіз ризиків проекту 3 розробкою проактивних протиризикових заходів.

На шостому етапі розглядається стан і плануються зміни у підсистемах, що відносяться до «м'якого компоненту» проектного менеджменту (що пов'язаний 3 людським фактором) - підсистемах управління стейкхолдерами, управління комунікаціями і частині підсистеми управління ресурсами, що розглядає управління командою і персоналом проекту ПМЕ.

На останньому, сьомому, етапі уточнюються інтегруючі, коригуючі, холістичні впливи, які необхідно здійснити на проект за результатами проведеного цілісного моніторингу, які далі впроваджуються.

Пропонований підхід, що включає сім етапів, які періодично реалізуються в проекті під час проведення планового моніторингу, містить проактивні, холістичні і синергетичні компоненти, що сприятиме глибині, якості і ефективності моніторингу проекту ПМЕ. Це, в свою чергу, забезпечуватиме отримання проектом ПМЕ потрібного результату в межах визначених обмежень і задоволення (або навіть перевищення) очікувань основних зацікавлених сторін щодо проекту.

\section{Висновки}

В статті представлена концептуальна модель проекту підвищення муніципальної енергоефективності. Модель поєднує чотири важливих аспекти - один технологічний і три управлінських, що стосуються організаційної, інформаційної і безпосередньо управлінської складової. Концептуальна модель проекту ПМЕ доповнена моделлю аналізу рішень щодо енергоефективності, підходом управління на основі холістичного бачення і підходом щодо проведення цілісного моніторингу про- 
екту ПМЕ. Запропоновані інструменти сприятимуть підвищенню якості управління проектом ПМЕ і збільшать ймовірність отримання ним запланованих результатів в межах визначених обмежень.

\section{Список літератури}

1. Шевцов А. І., Бараннік В. О., Земляний М. Г., Ряузова Т. В. Аналітична доповідь «Енергоефективність у регіональному вимірі. Проблеми та перспективи» Дніпропетровськ: Регіональний філіал Національного інституту стратегічних досліджень в м. Дніпропетровську. 2014. 78 с.

2. ДСТУ ISO 50001:2014. Системи енергетичного менеджменту. Вимоги та настанова щодо використання (ISO 50001:2011, IDT). К.: Мінекономрозвитку України, 2015. 27 с.

3. IPMA "Individual Competence Baseline" (ICB) Version 4.0 for Project, Programme \& Portfolio Management / IPMA, 2015. 431 p. URL: $\quad$ http://products.ipma.world/ipmaproduct/icb/read-icb/.

4. OGC. Portfolio, Programme and Project Management Maturity Model (P3M3) URL: https://www.axelos.com/best-practicesolutions/p3m3.

5. Руководство по управлению инновационными проектами и программами : т. 1 , версия 1.2 / пер. на рус. язык под ред. С. Д. Бушуева. К.: Наук. світ, 2009. 173 с.

6. A Guide to the Project Management Body of Knowledge (PMBOK ${ }^{\circledR}$ Guide) Sixth Edition / USA. PMI, 2017. 756 p.

7. Передача технологій // Українська дипломатична енциклопедія: у 2 т. / Л. В. Губерський (голова). К.: Знання України, 2004. T.2. М-Я. $812 \mathrm{c}$.

8. Бушуев Д. А. Механизмы переноса знаний программ развития организаций. Управление развитием сложных систем. 2016. №25. C. 11-16.

9. Редько В. С. Особливості холістичного управління в туризмі. Вісн. начіонального університету водного господарства та природокористування. Серія Економіка: зб. наук. пр. Рівне, 2014. № 1 (65). С. 331338.

10. Бушуєв С. Д., Козир Б. Ю. Інноваційні механізми управління програм розвитку морських транспортних кластерів. Управление развитием сложных систем. 2011. №7. C. 5-7.

\section{References}

1. Shevtsov, A. I., Barannik, V. O., Zemlyany, M. G., Riauzova, T. V. (2014) Energy efficiency in the regional dimension. Problems and perspectives. Analytical report. Dnipropetrovsk: Regional Branch of the National Institute for Strategic Studies in Dnipropetrovsk, 78 p.

2. DSTU ISO 50001: 2014 (2015) Energy Management Systems. Requirements and usage guidelines (ISO 50001: 2011, IDT). K.: Ministry of Economic Development of Ukraine, $27 \mathrm{p}$.

3. IPMA "Individual Competence Baseline" (ICB) Version 4.0 for Project, Program \& Portfolio Management (2015). IPMA, 431 p. URL: $\quad$ http://products.ipma.world/ipmaproduct/icb/read-icb/.

4. OGC (Office of Government Commerce). Portfolio, Program and Project Management Maturity Model (P3M3). URL: https://www.axelos.com/best-practicesolutions/p3m3.

5. Bushuyev, S.D. ed. (2009) Innovative Project and Program Management Guide: Vol. 1, Version 1.2. Kyiv. Science World, 173 p.

6. A Guide to the Project Management of the Knowledge (PMBOK® Guide) - Sixth Edition (2017). USA. PMI, 756 p.

7. Technology Transfer. Ukrainian Diplomatic Encyclopedia: 2 t. L.V. Hubersky (head). K. Knowledge of Ukraine, 2004. T.2, 812 p.

8. Bushuyev, D. A. (2016). Immune memory as a management tool enterprise development program. Management of Development of Complex Systems, 25, pp. 11-16.

9. Redko V. Y. (2014). Features holistic management in tourism. Visnyk natsional'noho universytetu vodnoho hospodarstva ta pryrodokorystuvannya: seriya Ekonomika: zbi. nauk. prats. 1(65), pp. 331-338.

10. Bushuyev S. D., Kozyr B. Y. (2011). Innovative mechanisms of management of sea transport cluster development programs. Management of Development of Complex Systems, 7, pp. 5-7. 


\section{Y. Skuro, Postgraduate \\ e-mail: skuro_mu@meta.ua \\ Kyiv National University of Construction and Architecture, av. Povitroflotskyi, 31, Kyiv, 03037, Ukraine \\ CONCEPTUAL MODEL OF PROJECT MANAGEMENT SYSTEM FOR INCREASING MUNICIPAL ENERGY EFFICIENCY}

The problem of raising the municipal energy efficiency is set. The application of the project approach to activities to increase municipal energy efficiency is substantiated. Analysis of the literature on energy efficiency has been conducted. The study of standards in the field of project management has been made.

Conceptual model of municipal energy efficiency improvement project is provided. Requirements for the conceptual model are formulated. The conceptual model includes four aspects - technological, organizational, managerial and informational.

It is postulated that in the conceptual model it is necessary to carry out the transfer of models of these aspects. The essential characteristics of each aspect for an efficient transfer are determined. The model for estimating energy efficiency solutions for the choice of optimal solution is formalized.

The approach of the holistic vision to the project of raising the municipal energy efficiency is formulated. Elements of the holistic vision in the individual subsystems of the project management system are defined.

The sequence of implementation of periodic holistic monitoring of the project for the increase of municipal energy efficiency has been developed. Conclusion on the effectiveness of these approaches is made.

Keywords: project management, municipal infrastructure, energy efficiency, holism, synergetics, proactivity.

Стаття надійшла 29.05.2018.

Рецензенти: Н. С. Бушуєва, д.т.н., професор,

В. В. Морозов, к.т.н., професор. 